\title{
Pengembangan Lembar Kerja Praktikum Scientific Menggunakan Model Problem Based Learning pada Pengukuran Daya 1 Fasa Menggunakan 3 Voltmeter
}

\author{
M. Fuadunnazmi \\ Program Studi Pendidikan Fisika, IKIP Mataram \\ E-mail : mr_fu_0001@yahoo.com
}

\begin{abstract}
Instrumentation of Electrical Measurement is one of the subjects taught in the second semester at Physical Department of IKIP Mataram. One of the subjects is a single phase power measurement. But the fact is that in the laboratory of Physical Department at IKIP Mataram still not providing tool for learning activities in the form of wattmeter. This study aims to develop a scientific jobsheet to measure a single phase electric power-assisted 3 pieces voltmeter as modifying the wattmeter. This research included in type of research and development in three stages: preliminary studies, design development, and test media. Subjects were students of the second semester Department of Physics of IKIP Mataram who are studying the subjects. The application of problem based learning models that are used to raise the authentic issue of energy-saving lamp power measurement that common released on the market. Based on the data analysis can be concluded that: (1) a single-phase power measurement can be carried out using 3 voltmeter and (2) the reduction occurred in the power absorption of the energy-saving lamp tested than the original 5 watts to 1.8 watts.
\end{abstract}

Keyword: Scientific, PBL, energy-saving lamp

\section{PENDAHULUAN.}

Listrik merupakan salah satu cabang keilmuan dalam bidang Ilmu Pengetahuan Alam (IPA) yang dapat dipelajari melalui studi gejalagejala kelistrikan. Instrumentasi Pengukuran Besaran Listrik merupakan salah satu mata kuliah dalam bidang kelistrikan yang membahas tentang cara mengukur gejala-gejala kelistrikan melalui pengukuran besaran-besaran listrik seperti kuat arus, beda tegangan, hambatan, induktansi, kapasitansi, daya, medan magnet, medan listrik, dan frekuensi. Mata kuliah tersebut juga diajarkan di Jurusan Pendidikan Fisika IKIP Mataram bagi mahasiswa semester II. Dalam konteks pengukuran besaran listrik terdapat beberapa topik yang dibahas antara lain: efek pembebanan, akurasi dan presisi, mempertinggi batas ukur, jembatan arus searah dan bolak-balik, serta pengukuran daya listrik satu fasa. Kendala utama yang dihadapi oleh para dosen fisika IKIP Mataram dalam mengajarkan topik pengukuran daya listrik satu fasa adalah tidak adanya alat ukur yang memadai berupa wattmeter sehingga pembelajaran pada topik ini seringkali disampaikan secara teoritis. Hal ini diasumsikan akan berdampak pada rendahnya ketercapaian learning outcomes yang dipersyaratkan pada mata kuliah tersebut.
Secara teoritis daya listrik merupakan besarnya energi listrik yang diserap oleh komponen-komponen listrik persatuan waktu. Terdapat tiga jenis daya listrik yaitu daya nyata, daya reaktif, dan daya kompleks. Pada diagram segitiga daya, perhitungan daya nyata diperoleh melalui hasil perkalian arus dan tegangan dengan nilai cosinus dari faktor daya. Secara vektor untuk pemasangan beban resistif dan induktif secara seri akan berdampak pada perbedaan phasor tegangan beban. Oleh karena itu perhitungan faktor daya sangat mungkin dilakukan melalui pengukuran tegangan beban resistif-induktif secara seri dan kombinasi.

Untuk meminimalisir tingkat kejenuhan mahasiswa dalam mempelajari topik ini, maka perlu didesain sebuah pembelajaran yang otentik berbasis masalah. Model pembelajaran berbasis masalah mendorong siswa berusaha belajar dalam memecahkan masalah dengan mengembangkan kemampuan menganalisis dan mengelola informasi berdasarkan pengalaman yang telah dimiliki ataupun pengalaman baru yang dihadapi siswa itu sendiri [5].

Salah satu tema otentik terkait pengukuran daya listrik satu fasa adalah pengukuran daya yang diserap oleh lampu hemat energi yang 
banyak beredar di pasaran. Oleh karena itu penelitian ini berfokus pada pengembangan lembar kerja praktikum scientific menggunakan model problem based learning dalam pengukuran daya satu fasa berbantuan tiga buah voltmeter.

\section{TINJAUAN PUSTAKA.}

Sains berupaya membangkitkan minat manusia agar mau meningkatkan kecerdasan dan pemahamannya tentang alam seisinya yang penuh dengan rahasia yang tiada habis-habisnya [1] Salah satu fenomena sains dalam kehidupan adalah listrik. Secara sederhana listrik dapat diartikan sebagai fenomena alam dengan gejalagejala keberadaan muatan positif (proton) dan atau muatan negatif (elektron) baik dalam keadaan diam atau statis maupun bergerak atau dinamis. Dalam tinjauan yang lain sains (IPA) diartikan sebagai suatu cara mencari tahu tentang alam secara sistematis untuk menguasai pengetahuan, fakta-fakta, konsep-konsep, prinsipprinsip, proses penemuan dan memiliki sikap ilmiah [2]. Sikap ilmiah memiliki beberapa tahapan yaitu pengamatan, membuat pertanyaan, penyelidikan, analisis data, dan menyimpulkan. Untuk memudahkan pengukuran sikap ilmiah mahasiswa dalam proses pembelajaran di kelas maka sangat diperlukan suatu rancangan Lembar Kerja Praktikum Scientific yang dapat memodelkan langkah-langkah proses pembelajaran ilmiah. Belajar IPA (Fisika) mencakup dua dimensi yaitu proses dan hasil, sehingga siswa tidak hanya sekedar mengingat saja apa yang telah dipelajari tetapi juga harus memiliki konsepsi yang benar [3]. Langkahlangkah berpikir ilmiah merupakan suatu metodologi atau cara yang dipakai untuk mengetahui sesuatu (riset pada umumnya) yang biasa disebut metode ilmiah [4].

Dalam dokumen Rencana Pembelajaran Semester (RPS), Lembar Kerja Praktikum (LKP) merupakan sebuah perangkat pembelajaran yang terintegrasi dengan model pembelajaran yang digunakan. Terdapat beberapa jenis model pembelajaran yang dapat diterapkan di kelas, salah satunya adalah model Problem Based Learning atau Pembelajaran Berbasis Masalah. Model pembelajaran berbasis masalah mendorong siswa berusaha belajar dalam memecahkan masalah dengan mengembangkan kemampuan menganalisis dan mengelola informasi berdasarkan pengalaman yang telah dimiliki ataupun pengalaman baru yang dihadapi siswa itu sendiri [5]. Dalam pengertian yang lain model pembelajaran berbasis masalah dilakukan dengan adanya pemberian rangsangan berupa masalah-masalah yang kemudian dilakukan pemecahan masalah oleh siswa yang dapat menambah keterampilan siswa dalam pencapaian materi pembelajaran [6].

Terkait dengan konsep pengukuran daya listrik, maka dapat diangkat sebuah tema otentik berupa pengukuran daya yang diserap oleh lampu hemat energi yang banyak beredar di pasaran. Secara berurutan model pembelajaran berbasis masalah mengarahkan peserta didik untuk melakukan pengamatan gejala kelistrikan otentik yang dihadapi dalam kehidupan sehari-hari. Fenomena kelistrikan otentik untuk memahami gejala-gejala yang terkait dapat dimodelkan dalam bentuk eksperimen berbantuan Lembar Kerja Praktikum scientific. Pengamatan tersebut harus dapat memancing peserta didik untuk bertanya produktif. Pada sesi selanjutnya pengajar harus mampu memberikan penjelasan ilmiah untuk menjawab pertanyaan-pertanyaan produktif dari peserta didik hingga dihasilkan kesimpulan.

Daya listrik merupakan besarnya energi listrik yang diserap oleh komponen-komponen listrik per satuan waktu. Jenis-jenis daya listrik dibagi menjadi tiga, yaitu: daya nyata, daya reaktif, dan daya kompleks. Daya nyata adalah daya listrik yang diserap oleh komponen yang bersifat resistif. Besar daya ini dirumuskan sebagai berikut:

$$
\begin{aligned}
& \mathrm{P}=\mathrm{V} \mathrm{I} \cos \varphi \ldots \ldots \ldots \ldots \ldots . . . . . . . . . . . .(1-1) \\
& \text { dimana: } \\
& \mathrm{P}: \text { Daya nyata/daya riil/daya aktif }(\mathrm{W}) \\
& \mathrm{V}: \text { Tegangan }(\mathrm{V}) \\
& \mathrm{I}: \text { Arus }(\mathrm{A}) \\
& \cos \varphi: \text { Faktor daya }
\end{aligned}
$$

Daya reaktif adalah daya listrik yang diserap oleh komponen-komponen yang bersifat reaktif yaitu berupa induktor dan kapasitor. Besar daya ini dirumuskan sebagai berikut :

$$
\mathrm{Q}=\mathrm{V} \mathrm{I} \sin \varphi \text {. }
$$


dimana:

Q: Daya reaktif / daya buta (VAr)

$\mathrm{V}$ : Tegangan $(\mathrm{V})$

I: Arus (A)

Daya kompleks disebut juga sebagai daya semu atau daya nampak. Daya ini merupakan penjumlahan vektor antara daya nyata dengan reaktif, yang dapat dirumuskan sebagai berikut :

$\mathrm{S}=\mathrm{P}+\mathrm{jQ}=\mathrm{VI}^{*}$ ..(1-3)

dimana:

S: Daya kompleks / daya semu / daya nampak (VA)

Ketiga jenis daya ini dapat dilukiskan ke dalam bentuk segitiga daya.

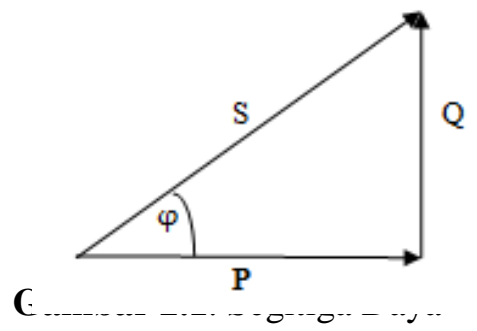

Pengukuran daya nyata arus bolak-balik satu fasa dengan menggunakan tiga voltmeter dapat dilakukan dengan cara sebagai berikut.

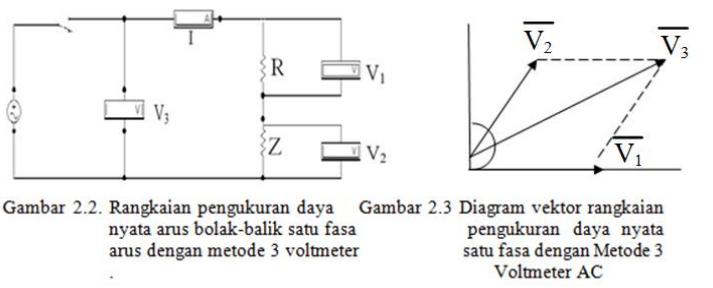

Allansss Kuallutall vesal naya yallg uiserap vien beban $\mathrm{Z}$ dari gambar 2.2 diperoleh :

$$
\begin{aligned}
& \mathrm{P}=\mathrm{V}_{1} \mathrm{I} \cos \varphi \text {. } \\
& \mathrm{I}=\frac{\mathrm{V}_{2}}{\mathrm{R}} \text {. }
\end{aligned}
$$

dan dari gambar 2.3:

$$
\mathrm{V}_{3}^{2}=\mathrm{V}_{1}{ }^{2}+\mathrm{V}_{2}{ }^{2}+2 \mathrm{~V}_{1} \mathrm{~V}_{2} \cos \varphi \text {. }
$$

6)

Dengan demikian, dari persamaan (1-6) dapat diperoleh penurunan harga $\cos \varphi$ sebagai berikut:

$$
\cos \varphi=\frac{\mathrm{V}_{3}{ }^{2}-\mathrm{V}_{1}{ }^{2}-\mathrm{V}_{2}{ }^{2}}{2 \mathrm{~V}_{1} \mathrm{~V}_{2}}
$$

Dengan substitusi persamaan (1-5) dan (1-7) ke dalam persamaan (1-4) diperoleh persamaan $\mathrm{P}=$ $\mathrm{f}\left(\mathrm{V}_{1}, \mathrm{~V}_{2}, \mathrm{~V}_{3}\right)$ sebagai berikut :

$$
\begin{aligned}
& \mathrm{P}=\mathrm{V}_{1}\left(\frac{\mathrm{V}_{2}}{\mathrm{R}}\right)\left(\frac{\mathrm{V}_{3}{ }^{2}-\mathrm{V}_{1}{ }^{2}-\mathrm{V}_{2}{ }^{2}}{2 \mathrm{~V}_{1} \mathrm{~V}_{2}}\right) \\
& \mathrm{P}=\frac{\mathrm{V}_{3}{ }^{2}-\mathrm{V}_{1}{ }^{2}-\mathrm{V}_{2}{ }^{2}}{2 \mathrm{R}} \text {. }
\end{aligned}
$$

Dimana:

$\mathrm{P}$ : Daya nyata yang diserap beban $\mathrm{Z}$ (W)

$\mathrm{V}_{1}$ : Tegangan terukur pada impedansi beban $\mathrm{Z}(\mathrm{V})$

$\mathrm{V}_{2}$ : Tegangan terukur pada $\mathrm{R}(\mathrm{V})$

$\mathrm{V}_{3}$ : Tegangan terukur pada sumber $(\mathrm{V})$

I: Arus sumber (A)

R: Tahanan Refferensi $(\Omega)$

$\cos \varphi$ : Faktor daya.

\section{METODE PENELITIAN.}

Penelitian ini termasuk jenis penelitian dan pengembangan pendidikan (Educational Research and Development). Jenis penelitian R \& $\mathrm{D}$ adalah suatu proses yang digunakan untuk mengembangkan dan memvalidasi produkproduk pendidikan [5]. dalam penelitian ini dikembangkan perangkat pembelajaran Lembar Kerja Praktikum Scientific menggunakan model Problem Based Learning pada pokok bahasan pengukuran daya satu fasa menggunakan tiga buah voltmeter. Secara umum penelitian dilakukan dalam tiga tahapan, yaitu: tahap studi pendahuluan, tahap pengembangan desain, dan tahap pengujian model. Subjek penelitian adalah mahasiswa Jurusan pendidikan Fisika IKIP Mataram semester dua yang sedang menempuh mata kuliah Instrumentasi Pengukuran Besaran Listrik.

\section{HASIL DAN PEMBAHASAN.}

Tabel 1 memperlihatkan hasil pengukuran tegangan berturut-turut $\mathrm{V}_{1}, \mathrm{~V}_{2}$, dan $\mathrm{V}_{3}$ untuk tegangan beban $\mathrm{R}$, tegangan beban $\mathrm{Z}$ (mengandung komponen induktif pada komponen ballast lampu hemat energi), dan tegangan resultan kedua beban. Nilai hambatan $\mathrm{R}$ terukur adalah $470 \mathrm{ohm}$ sedangkan nilai hambatan $\mathrm{Z}$ terukur adalah $22 \mathrm{ohm}$. Adapun besar daya yang tertera pada lampu uji hemat energi adalah sebesar 5 watt. Untuk menguji reliabilitas data maka dilakukan sebanyak dua kali percobaan dengan parameter data yang sama.

Tabel 1. Hasil pengukuran $\mathrm{V}_{1}, \mathrm{~V}_{2}, \mathrm{~V}_{3}$, dan $\mathrm{I}$

\begin{tabular}{|c|c|c|c|c|}
\hline $\begin{array}{c}\text { Percobaa } \\
\text { n ke - }\end{array}$ & $\mathrm{V}_{1}$ & $\mathrm{~V}_{2}$ & $\mathrm{~V}_{3}$ & $\mathrm{I}$ \\
& (Volt & $($ Volt & $($ Volt & (Ampere \\
& ) & ) & ) \\
\hline
\end{tabular}




\begin{tabular}{|c|c|c|c|c|}
\hline 1 & 9,7 & 211 & 220 & 0,01 \\
\hline 2 & 11,6 & 219 & 228 & 0,01 \\
\hline
\end{tabular}

Berdasarkan pada data hasil pengamatan yang tersaji pada Tabel 1, besar arus (I) yang didapat pada percobaan I dan II adalah sama yaitu 0,01 ampere, sedangkan besar tegangan $(\mathrm{V})$ yang didapat dari kedua percobaan adalah berbeda. Pada percobaan I, nilai $\mathrm{V}_{1}$ adalah 9,7 Volt, $\mathrm{V}_{2}$ sebesar 211 Volt, dan $\mathrm{V}_{3}$ sebesar 220 volt. Pada percobaan II, nilai $\mathrm{V}_{1}$ sebesar 11,6 Volt, $\mathrm{V}_{2}$ sebesar 219 Volt, dan $\mathrm{V}_{3}$ sebesar 228 volt.

$\mathrm{V}_{1}$ menunjukkan tegangan terukur pada beban $\mathrm{R}$, $\mathrm{V}_{2}$ menunjukkan tegangan terukur pada beban $\mathrm{Z}$ (lampu), dan $\mathrm{V}_{3}$ merupakan tegangan sumber dan resultan dari kedua tegangan beban. Setelah dilakukan perhitungan diperoleh nilai faktor daya $(\cos \varphi)$ dari percobaan I adalah 0,9 sedangkan pada percobaan II sebesar 0,8. Melalui perhitungan menggunakan persamaan (1-4) sampai (1-8) baik pada percobaan I maupun percobaan II didapatkan hasil yang sama yaitu sebesar 1,8 watt. Oleh karena itu terdapat perbedaan antara daya yang tertera pada beban lampu uji hemat energi dengan daya yang diperoleh melalui pengukuran dan perhitungan analisis data menggunakan 3 buah voltmeter.

\section{PENUTUP.}

Berdasarkan hasil analisis data pengujian dapat ditarik kesimpulan bahwa: (1) pengukuran daya satu fasa dapat dilakukan menggunakan 3 buah voltmeter dan (2) terjadi reduksi penyerapan daya pada lampu uji hemat energi dari yang semula 5 watt menjadi 1,8 watt.

\section{UCAPAN TERIMA KASIH.}

Terima kasih yang sebesar-besarnya penulis sampaikan kepada Bapak Dr. Gunawan, M.Pd., selaku Ketua Dewan Redaksi serta rekan-rekan yang terlibat dalam proses penyuntingan hingga penerbitan artikel ini dalam Jurnal Pendidikan Fisika dan Teknologi (JPFT) FKIP Unram.

\section{REFERENSI.}

[1] Gunawan. 2015. Model pembelajaran sains berbasis ICT. Mataram: FKIP Universitas Mataram.

[2] Putra, Sitiatava Rizema. 2013. Desain Belajar Mengajar Kreatif Berbasis Sains. Yogyakarta: Diva Press.

[3] Khasanah, Nunung. 2010. Penggunaan Pendekatan Konflik Kognitif untuk Remidiasi Miskonsepsi Pembelajaran Usaha dan Energi. Tesis Program Studi Pendidikan Sains Universitas Sebelas Maret.

[4] Smith.P.L \& Ragan.T.L. 2003. Instructional Design. Upper Saddle River, NJ. Merril Prentice Hall Inc.

[5] Sugiyono. 2012. Statistik untuk Penelitian. Bandung: Alfabeta.

[6] Suprijono, A. 2009. Cooperative Learning. Surabaya: Pustaka Belajar. 